\title{
The Use of Conversation Diary in Enhancing Students' English Speaking Skill
}

\section{Ria Anugrah Prasanti ${ }^{*}{ }^{*}$, Lasim Muzammil2, Oktavia Widiastuti ${ }^{3}$}

1,2,3 Master of English Education Study Program, Universitas Kanjuruhan Malang

\section{A R T I C L E I N F 0}

Article history:

Received February

2020

Received in revised

Form 01 March 2020

Accepted 18 April 2020

Available online 30 May

2020

\section{Keywords:}

Enhance, Speaking,

Diary, Media

\section{A B S T R A C T}

This research describes the use of Conversation Diary as a strategy in increasing students' English speaking skill and discovers the decreasing of students' anxiety in performing English speaking. This research is done in Classroom Action Research (CAR) within 2 cycles. Each of the cycle is started by assessing classroom problems, and continues with planning, acting, observing, and reflecting. Each cycle has four meetings to accomplish. The participants of this study were 30 students. They got Conversation Diary treatment during eight weeks. Test 1 and test 2 were conducted to get numerical data while interview, observation checklist, and questionnaire were used to get verbal data needed. The finding informed that cycle 1 failed. It was because most of students' vocabulary and grammar understanding were still low, caused by length and frequency of time which was too short. On the other hand, from verbal information data, it is found that the students' behaviour has changed. However, cycle 2 is still needed. Cycle 2 showed students' behaviour were increased. The students' score test 3 reached minimum score. In conclusion, this study proved that Conversation Diary could improve the students' speaking skill better and help decreasing the students' anxiety. With enough length of time, it would gain better result. 


\section{Introduction}

Speaking is one of the language skills that are taught on all level, it also has been considered as the most challenging skill since it needs a complex process of constructing meaning (Juan \& Flor, 2006). Practice everyday is a strategy in learning English. English teacher of Learning English class 101 (Kreutzer \& Ivelich, 2017) stated that by practicing English everyday, it makes the students will be accustomed to speak English. Yet, anxiety is the main problem in learning second language (Sato, 2003). Students feel anxious and nervous when they speak. It may be due to that they do not have good skill, or most of the students are lack of vocabulary and they do not practice much. Therefore, preparation is required. Most of the students need time to arrange about what they want to talk and the way to speak because it hard for them to concept, formulate, and simulate the articulation of the topic that they want to talk without any preparation before speaking (Wang, 2014). Pre-task is a crucial way that can reduce students' anxiety easily (Goh, 2007). In pre-task activity, the students have enough time to plan and they are allowed to find some of references that support them in speaking (Skehan, Willis, \& Willis, 1996). It also leads the students to get more related vocabularies and some information that give them idea, so it avoid them from failure conversation (Horwitz, 2001).

One way to have the student prepared is by asking the student to think and write about their idea; it will help them talk easily. For instance, there is diary. It is kind of media to write the students' experience or idea. Diary gives students the chance to tell the story of their current language learning (Oxford, Lavine, Felkins, Hollaway, \& Saleh, 1996). Writing diary is also help the student to prepare about what they are going to say include grammar, vocabulary, and pronunciation. Keeping a language learning diary helps learners become more aware of their strategies at any given time and across along period (Oxford et al., 1996).

LP3I is an educational institution that prepares the students to work and English proficiency is one of the requirements at work place. Therefore, the students are taught to communicate in English better. English conversation is one of the compulsory subjects at LP3I Sidoarjo to enhance the students' communication capability. Unfortunately, during the process of teaching and learning in English Conversation class the researcher found that most of the student felt anxiety, nerves, and shy. Then, Conversation Diary found as a strategy at LP3I Sidoarjo in term of to support English Conversation class in order to enhance students' English speaking skill.

The use of diary in helping the students to prepare to communicate orally also discussed by Nakatami. In a study with title The Effects of Awareness-Raising Training on Oral Communication Strategy Use,(Nakatani, 2005) said that Oral Communication Strategy (OCS) is a strategy that focus on the process of speaking behavior between the speaker and the person who are they speaking to. The finding of this study was indicated that the students improved their pronunciation, grammar and they gained a lot of vocabulary as well.

Alonso shows another study related to the use of writing as a strategy. In Learning diaries to learner autonomy in mixed-ability group said that Learning Diaries could help the students to perform better (Alonso, 2011). El-Koumy (1998) stated in a study Effect of Dialogue Journal Writing on EFL Students' Speaking Skill that Dialogue Journal Writing helped the student to speak English naturally without any anxiety. It also motivated the students to learn speaking English and gave the student a change to have communication in English with their teacher.

Based on the discussion above, there were similarity and difference between those of the previous study above and the researcher's study. The similarity is that most of the study used writing strategy to enhance the students' English speaking skill. On the other hand, the implantation of the writing strategy was quite different. The first study used OCS as a strategy. OCS takes an advantage of a book containing of expressions to help the students speaking English. In addition, there was a diary that the students can construct a scheme, observe, and assess their own performance on it. The second study required the students to write their diary in an e-mail. The students write their personal interest and their country culture. The third study there was dialogue journal writing that required the students to make a dialogue before speaking practice. The students allowed seeing the activity book that provided variety of expression. Then, Conversation Diary is seen as a relatively new invention that contains eight topics where the students required write their own idea according to the topic given. This study tries to combine conversation and writing to enhance the students' speaking English skill. 


\section{Methods}

The research had done in Classroom Action Research. The aim of this study is to solve the problem concerning students' speaking skill. The process of implanting of CAR consisted of two cycles that included four steps in interconnected. They are first Plan. It is a step to prepare the classroom instructional strategy to be developed in the study to solve the instructional problem (Latief, 2012). The plans contain of three main points, they were preparing the strategy, lesson plan and determined the standard of the success to measure the effectiveness of the strategy. Second was Acting. Acting is a phase to implement the instructional strategy that has been planned. At the first meeting, the students got their conversation diary booklet. After that, the students were required to write their own idea according to the topic given. The students were allowed to acquire all the information that related to the topic given through various kinds of the media, such as internet, magazine, newspaper or directly from the informant. Nevertheless, the students were forbidden to copy paste from the internet or cheating from their friends. The next activity, the students get an interview from the researcher in turn. In the second meeting, the interview continued. The students get some reviews about their mistakes during the interview process at the last section of the second meeting. At the third and the forth meeting, the student got the same treatment as the first and the second meeting but in different topic. In the process of the interview, the students got some questions that related to the topic they talk about. There was assessment made by the interviewer as well.

The Conversation Diary collected to the researcher to get the writing score and review. After the process of the Conversation Diary treatment, the student got the second test. Similar with the first test, the students were tested through an interview and each of students were interviewed on same topic. There was an assessment, which the aim is to figure out the progress of the student speaking skill after they get conversation diary treatment. In the last phase, the researcher got two data score; they were the first test score that obtained from the observation and the second test score. Next, the researcher compared the students' first test score with the students' second test score. From the comparison, the researcher analyzed the result of data score comparison. By doing so, it found which strategy has trouble outcome. With the result, the second cycle was needed. The third was observing. Observing was the process of collecting data indicating the success of the strategy in solving the classroom problem (Latief, 2012). There were numerical and verbal information data that took from the test and interview. The Instrument included observation checklist, test, interview, and questionnaire. The fourth was reflecting. Reflecting was the process of analyzing data to determine how far the data collected have shown the success of the strategy in solving the problem (Latief, 2012). In this stage, the researcher analyzed the data to determine whether the data collected have shown the success or not. Unfortunately, the targeted criteria of success in the cycle 1 did not achieve, and then the cycle 2 was needed.

Cycle 2 was done as a revision of cycle 1 . The steps were the same as in cycle 1 . There were planning, acting, observing and reflecting. However, a new method was applied in cycle 2 to support the Conversation Diary in order to reach the criteria of success.

\section{Result and Discussion}

In the preliminary study, the researcher observed the students' behavior during teaching and learning process by interviewing the previous lecturer when the conversation diary had not used before. From the interview, it can be conclude that there were internal factors and external factors that influence the students' ability in speaking English. Students' awareness on the importance of English as global communication is one of internal factors that influence the students in learning speaking English. Most of the students thought that they did not need to learn English because the second foreign language speaker only used by native speaker but not such a tool for communication that broadly uses English. The students also thought that learning English is only for credits and examination (Tsuda, 2003). The external factors that influence the students in learning English are target language exposure. Nowadays, Korean drama and music are more popular than English movie and song. As a result, the students are more familiar with Korea language then English. Teaching approaches is another factor that influences the students' in learning English. Most of the teacher tends to use Indonesia than English though in English class. It makes the target language exposure merely tend their own mother tongue than English.

In the observing, the researcher conducted two tests. The first test was on 18 February 2019 and the second was on 8 April 2019. The first test conducted before the students got Conversation Diary. The students were examined through an interview without any preparation. 


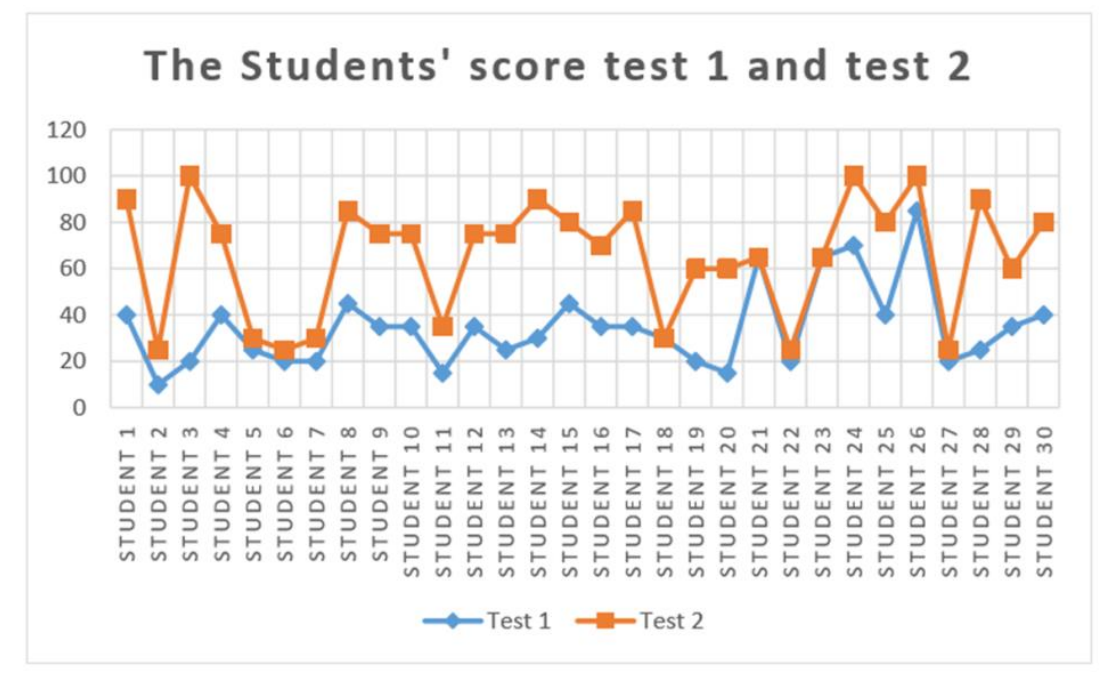

Picture 1. Chart The Students' Score Test 1 and Test 2

Each of students was interviewed in the same topic; let's talk about food. Three open questions should be answer by the students. The result showed that the students' score was under the standard of the competencies achievement. It indicated that most of the students' speaking English skill was low. The second test was conducted after the implantation of Conversation Diary. Similar with the first test, the students tested through an interview and each of students interviewed on same topic; let's talk about vacation. (See Chart 1 . The students' test 1 and test 2 score). The result of the second test indicated that the students' score were increasing. It is because Conversation Diary is a booklet that arranged quite different with the task book. There were four topics provided without any grammar and vocabulary direction. It pushes the students to think creatively in expressing their ideas, suggestions and opinion that based on the topic given. The students were also allowed to get references from the internet and ask or discuss with their friends as informant.

Next observing, the researcher examined the students' anxiety by means of questioner. The examination was conducted in two sections. The first examination was conducted before the implantation of Conversation Diary and the second was after the implantation of Conversation Diary. At the first test, the result showed that most of the students were afraid, unconfident to speak English and felt apathetic to join English Conversation class. On the other hand, the result of second anxiety examination showed that the students were not afraid anymore, yet feeling confident to speak English and they were enthusiastic to join English Conversation Class. (See Chart 2 the students' anxiety examination result).

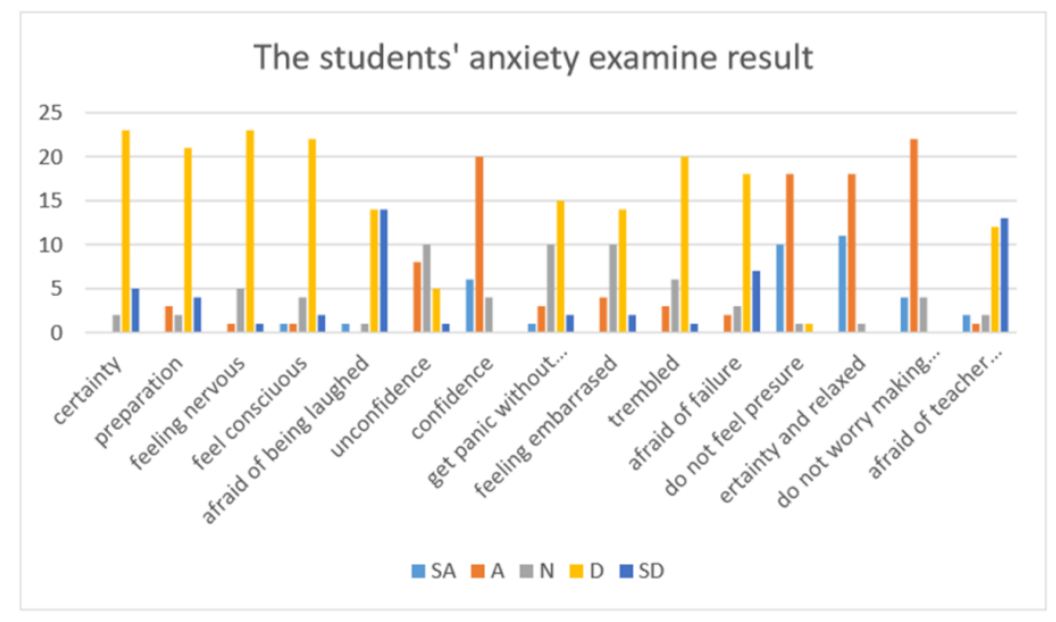

Picture 2. Chart The Students' Anxiety Examination Result 
In Reflecting step, the researcher compared students' score test 1 and students' score test 2 whether to know that the implementation of Conversation Diary had been achieved the criteria of success or not. In the first test, the result showed that most of students' score was under the standard of achievement competencies. The Mean was $\bar{x}=34$ and there were only $6.6 \%$ students whose score were reach the minimum standard of achievement competency. On the other hand, the result of second test showed that most of students' score were increasing. It can be proved by statistic descriptive result that the Mean was $=65$ and there were about $53.4 \%$ students whose score were reach the minimum standard of achievement competencies. It indicated that the students' behavior was increasing. Though the students score test 2 had not been yet achieved the minimum score; 75. It means that the revised cycle was needed.

Table 1. The Students' Grammar and Vocabulary Score

\begin{tabular}{lccc}
\hline & $\overline{\overline{\mathbf{X}}}$ & Max & Min \\
\hline Grammar Score & 12.50 & 20 & 5 \\
Vocabulary Score & 13.50 & 20 & 5 \\
\hline
\end{tabular}

From table 1, It can be seen that Mean of grammar score was $=12.30$, Mean of vocabulary score was $=13.50$ and the minimum score of grammar and vocabulary were min=5 from the maximum score 20 . It indicated that most of the students were lack on vocabulary and their understanding in grammar was low. (See table 1. The students' grammar and vocabulary score).

There was the third test after implementing Conversation Diary in cycle 2 as an improvement of the cycle 1 . The result showed that students' score was increased significantly. It can be seen from table 3 that students' score test was 3 , Mean was $=79.83$. It showed that there were about $80 \%$ students reached the minimum standard of achievement cmpetencies. (See Chart 3. The students' score test 3)

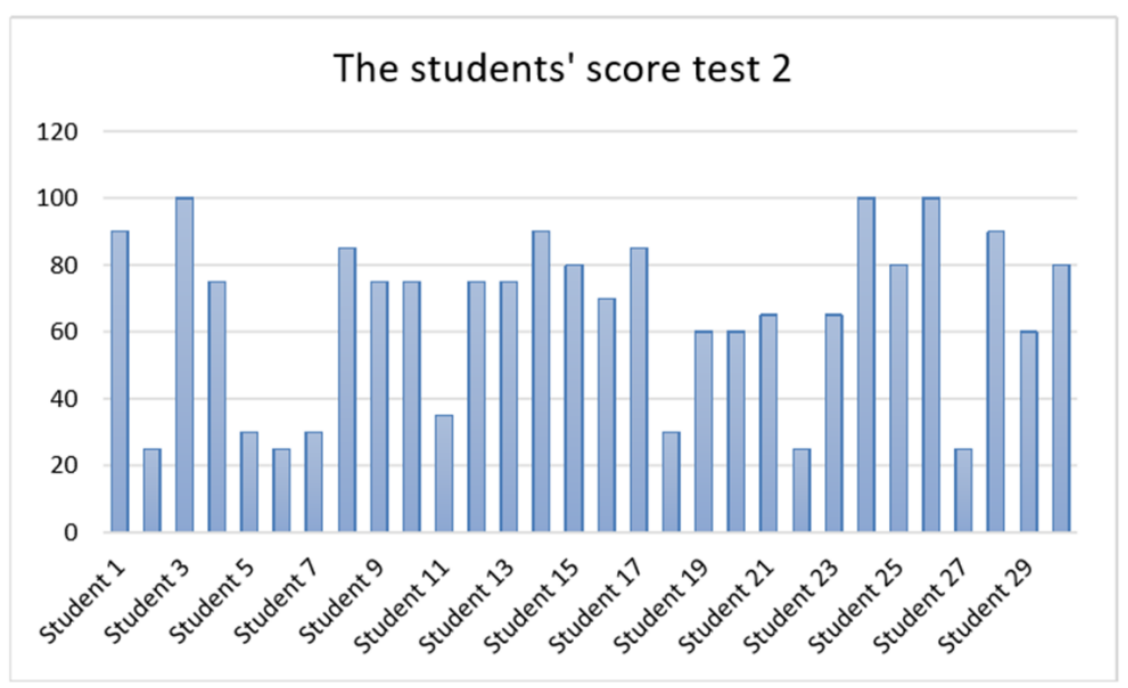

Picture 3. Chart The Students' Score Test 2

The classroom action research involved repeated cycles. In this study, the researcher conducted two cycles. The first cycle unsuccessful because the Mean was under minimum score $=65 \leq 75$. It indicated that student's score had not yet reached the minimum score. Though there was found that students' behavior increased about 50\% (X=34 to $=65)$. However, the revise cycle was needed. Based on the observation result of student's score, it showed that students' vocabulary and grammar understanding were still low. After the implantation of Conversation Diary in cycle 2, the students' score in Test 3 increased significantly and the Mean was $=79.83$. It indicated that cycle 2 was successful. This result was in line with Nakatani (2005), in his research, he found that the use of strategy diary was significantly improve the students' speech. It was examined by paired-sample t test (two-tailed). In the training group the Mean was gain about 1.38 from $=2.23$ to $=3.61$. On the other hand, the control group only gain about 0.25 from $=2.41$ to $=2.66$. However, some differences found that it could be weakness of the researcher. 
The usage of the diary was to review and evaluate students' progress that had done by the students. Therefore, it made students understand about their weakness. It helped them to prepare what they have to learn next. Reversal the previous subject, and guide them to the next subject (Nakatani, 2005). Frequency of time was the strength of this research. The researcher conducted this study two to three weeks continually everyday. It means that students have enough time to memorize vocabulary and practice thir pronunciation. As a result, their pronunciation was getting better. Contrary to the researcher study, there were only four weeks in first cycle and in each week about 180 minutes. Four weeks were not sufficient time for memorizing vocabularies and understanding the uses of grammar. As (Goh, 2007) stated that the students should master basic vocabulary and grammar to increase their speaking in target language.

In Nakatami (2005) research, the examiner was a native. On the other hand, in this research the examiners are the researchers themselves who are known well by the students. As a result, the students are quite easy to understand what the interlocutor said, because they have the same accent. Therefore, the scoring was not accurate. The next difference was the procedure of writing Conversation Diary. In Nakatami (2005) research, strategy diary was not merely for writing ideas, opinions, and suggestion that based on the topic given.

On the other hand, Nakatani (2005) subjects were selected randomly without considering to the students' ability. It means the students were in different level. In our opinion, this condition will influence the accuracy of the assessment process. It was quite different from Alonso (2011). He conducted the research to the students who have different English speaking skill. Alonso (2011) argued that learning diary could improve the students' English communication no matter what the students' English level proficiency. Therefore, he classified those students in three levels. From the Alonso' results, it can be proved that there were $80.56 \%$ from students in three level that used learning diary achieved the target. On the other hand, the students that did not use learning diary there were only $54.17 \%$ who achieved the target. E-learning instead hand writing that made the students more interesting also supported it.

Opposing to El-Koumy (1998), he needed about six month for his study. Therefore, the students had sufficient time to master vocabulary and grammar basic. In El-Koumy (1998), there were five steps arranged for the test. The first was reading. The scoring based on the pronunciation. Second, sentences test by completed a sentence in oral. Third, retelling a story by picture series sequence. Fourth, answering some question completely. Fifth, describing and retelling by using media visual. In our opinion, those of the sequent of the test probably can make the students more focus to the each of proficiency because the students were tested each of the proficiency in the different time. Therefore, the students will finish the test easily and got good score. It was quite different from the researcher' study. The students were tested five English proficiency in one time. Though the researcher merely focus on the students English performing.

The successful of this study can be proved by the students' anxiety examine result and the observation check list explanation. Result of students' anxiety showed that students' attitudes and motivation in Conversation class by using Conversation Diary as a media has changed. The comparative percentage that obtained from the anxiety examine items indicated that students' responses toward the implementation of Conversation Diary in teaching English Conversation was extremely good. The result of this study is beneficial theoretically and practically for teachng and learning process. Theoretically, this study contributes to the new strategy in learning speaking. Practically, this study provides a comprehensive instruction related to the application of conversation diary in the language learning process.

\section{Conclussion}

This study investigated the effect of implementation of Conversation Diary on the students' English speaking skill of LP3I students group F1. The finding indicated that students' English speaking skill significantly increased compare to students' English speaking skill before they got Conversation Diary treatment. Conversation Diary provides some activities that help students' preparation to achieve the target language. First, students gained more vocabularies, dictions, and information through internet. By using internet resources students think out of the box instead of focusing on textbook. The students wrote without any boundaries. Yet, it makes them more enthusiastic in writing. Second, the students got interview on their Conversation Diary writing. Having interview helps the students accustomed speaking to others. Moreover, they decreased their anxiety. As a result, Most of the students felt confident when they were speaking English in front of class though without any preparation. Thus, the students were motivated and more enthusiastic in learning English Conversation. They were active giving opinions, suggestions, and became more creative in expressed their idea. 


\section{Reference}

Aida, Y. (1994). Examination of Horwitz, Horwitz, and Cope's construct of foreign language anxiety: The case of students of Japanese. The modern language journal, 78(2), 155-168.

Alonso, A. C. (2011). Learning diaries to Foster learner autonomy in mixed-ability groups. Tejuelo: Didáctica de la Lengua y la Literatura. Educación(11), 47-63.

Amir, H. $\quad$ (Producer). (2013). $\quad$ Speaking $\quad$ skills. $\quad$ Retrieved from https://www.slideshare.net/zeal_eagle/speaking-skills-24884424

Ary, D., Jacobs, L. C., \& Razavieh, A. (2010). Introduction to research in education 8th edition, Wardswoth Cengage Learning. Canada: Nelson Education Ltd Exotic Classic.

Azizifar, A., Faryadian, E., \& Gowhary, H. (2014). The effect of anxiety on Iranian EFL learners' speaking skill. International Research Journal of Applied and Basic Sciences, 8(10), 1747-1754.

Barrett, K. C., Morgan, G. A., Leech, N. L., \& Gloeckner, G. W. (2011). IBM SPSS for introductory statistics: Use and interpretation. New York: Routledge.

Brown, H. D. (2000). Principles of language learning and teaching. In. New York: Pearson Education.

Creswell, J. W. (2012). Educational research : Planning, conducting, and evaluating quantitative and qualitative research. Boston: Pearson.

El-Koumy, A. S. (Producer). (1998). Effect of Dialogue Journal Writing on EFLStudents' Speaking Skill. Retrieved from https://files.eric.ed.gov/fulltext/ED502908.pdf

Faucette, P. (2001). A pedagogical perspective on communication strategies: Benefits of training and an analysis of English language teaching materials. University of Hawai'I Second Langauge Studies Paper 19 (2).

Fraenkel, J. R., Wallen, N. E., \& Hyun, H. H. (1993). How to design and evaluate research in education. New York: McGraw-Hill

Fromkin, V., Rodman, R., \& Hyams, N. (2011). An introduction to language: Cengage Learning.

Goh, C. C. M. (2007). Teaching speaking in the language classroom: SEAMEO Regional Language Centre Singapore.

Harris, D. P. (1969). Testing English as a Second Language. New York: McGraw-Hill.

Horwitz, E. (2001). Language anxiety and achievement. Annual review of applied linguistics, 21, 112-126.

Horwitz, E. K., Horwitz, M. B., \& Cope, J. (1986). Foreign language classroom anxiety. The modern language journal, 70(2), 125-132.

Huberty, T. J. (2009). Test and performance anxiety. Principal leadership, 10(1), 12-16.

Hughes, R. (2011). Teaching and Researching: Speaking. Great Britain: Pearson Education.

Juan, E. U., \& Flor, A. M. (2006). Current trends in the development and teaching of the four language skills. New York: Walter de Gruyter. 
Kemmis, S., McTaggart, R., \& Nixon, R. (2014). Introducing critical participatory action research. In The action research planner (pp. 1-31): Springer.

Koshy, V. (2005). Action research for improving practice: A practical guide. London: Sage.

Kreutzer, M., \& Ivelich, A. (2017). Fix Your Bad English in 50 minutes!. New York. Retrieved from https://www.youtube.com/watch?v=0I2wQwtzHX0\&t=135s

Latief, M. A. (2012). Research methods on language learning: An introduction. Malang: Universitas Negeri Malang Press.

MacIntyre, P. D., \& Gardner, R. C. (1991). Investigating language class anxiety using the focused essay technique. The Modern Language Journal, 75(3), 296-304.

Nakatani, Y. (2005a). The Effects of Awareness-Raising Training on Oral Comunication Strategy Use. The modern language journal, 89.

Nakatani, Y. (2005b). The effects of awareness-raising training on oral communication strategy use. The modern language journal, 89(1), 76-91.

Oxford, R. L., Lavine, R. Z., Felkins, G., Hollaway, M. E., \& Saleh, A. (1996). Telling their stories: Language students use diaries and recollection. In R. L. Oxford (Ed.), Language learning strategies around the world: Cross-cultural perspectives (pp. 19-34). Honolulu.

Peterson, S. S. (Producer). (2000). Pronunciation Learning Strategies: A First Look. Retrieved from https://files.eric.ed.gov/fulltext/ED450599.pdf

Richards, J. C., \& Schmidt, R. W. (2013). Longman dictionary of language teaching and applied linguistics. London: Routledge.

Sato, K. (Producer). (2003). Improving Our Students' Speaking Skills: Using Selective

Error Correction and Group Work To Reduce Anxiety andEncourage Real Communication. Retrieved from https://files.eric.ed.gov/fulltext/ED475518.pdf

Shumin, K. (2002). Developing Adult EFL Students' Speaking Abilities In Methodology in Language Teaching: An Anthology of Current Practices. Cambridge: Cambridge University Press.

Skehan, P. (1996). Second language acquisition research and task-based instruction. In J. Willis \& D. Willis (Eds.), Challenge and change in language teaching. Oxford: Heinemann

Tsuda, S. (2003). Attitudes toward English language learning in higher education in Japan (2): Raising awareness of the notion of global English. Intercultural Communication Studies, 12(3), 61-75.

Wang, Z. (2014). Developing Accuracy and Fluency in Spoken English of Chinese EFL Learners. English Language Teaching, 7(2), 110-118.

Woodrow, L. (2006). Anxiety and speaking English as a second language. RELC journal, 37(3), 308-328.

Yule, G. (2016). The study of language. Cambridge: Cambridge university press.

Zhang, Y., \& Jia, G. (2006). Anxiety in foreign language classroom. CELEA Journal, 29(6), 96-103. 